\title{
Effects of the Intrinsic Motivation and Extrinsic Motivation on Employee Performance with Job Satisfaction as an Intervening Variable at PT. Alwi Assegaf Palembang
}

\author{
Muhammad Yusuf \\ Politeknik Negeri Sriwijaya \\ Email: m.yusuf@polsri.ac.id
}

\begin{abstract}
This study aimed to examine and analyze the effects of intrinsic motivation and extrinsic motivation on the performance of employees with job satisfaction as an intervening variable at PT. Alwi Assegaf Palembang. The number of the respondents was 51 people. The data were collected using a questionnaire method with a Likert scale. They were examined and analyzed using the Smart-partial least square. Furthermore, the intrinsic motivation variable showed a significant positive influence on employee performance, but the extrinsic motivation variable did not have significant influence on the performance of the employees. The job satisfaction was not an intervening influence between intrinsic motivation and employee performance and between extrinsic motivation and employee performance. The results showed that intrinsic motivation and extrinsic motivation had a significant positive effect on the employee job satisfaction. The effect of the intrinsic motivation on the performance was significantly positive, while the extrinsic motivation was not significantly positive on the performance. In this study, the job satisfaction was not an intervening variable between the intrinsic and extrinsic motivations on the performance.
\end{abstract}

Keywords: Intrinsic Motivation, Extrinsic Motivation, Job Satisfaction, Employee Performance

\begin{abstract}
Abstrak
Penelitian ini bertujuan untuk menguji dan menganalisis pengaruh motivasi intrinsik dan motivasi ekstrinsik terhadap kinerja karyawan dengan kepuasan kerja sebagai variable intervening pada PT. Alwi Assegaf Palembang. Responden dalam penelitian ini berjumlah 51 orang. Data dalam penelitian ini diperoleh dengan menyebarkan kuisioner berupa pertanyaan dengan menggunakan skala Likert. Data dianalisis dengan smart-partial least square. Hasil penelitian menunjukkan bahwa motivasi intrinsic dan motivasi ekstrinsik berpengaruh positif signifikan terhadap kepuasan kerja karyawan. Pengaruh motivasi intrinsik terhadap kinerja adalah positif signifikan, sedangkan motivasi ekstrinsik menunjukkan tidak ada pengaruh signifikan positif terhadap kinerja. Kepuasan kerja bukan merupakan variabel intervening antara motivasi intrinsik dan ekstrinsik terhadap kinerja dalam penelitian ini.
\end{abstract}

Kata kunci: Motivasi Intrinsik, Motivasi Ekstrinsik, Kepuasan Kerja, Kinerja

\section{Introduction}

In an effort to gain profits, a company through its management must be able to become a mediator between business goals and the means to achieve these goals. The clear business goal is obviously to seek profit, but how to achieve the goals, among other things, the company and its human resource management must prioritize their human resource since it is the main driving force of the company. Consequently, the human resource has to be definitely motivated to keep contributing to achieving the goals.

PT. Alwi Assegaf is an ice block producing company that was founded in 1929 and the ownership status is a family company. This company produces ice block as the main product sold to fishermen and other users. The company expanded its business in an effort to increase profits at that time by establishing a rice mill and a timber processing company, unfortunately they had to be closed for the company was unable to compete with other similar companies. In the era of 1940 - 1970 the company was able to meet the market demand and produced up to 200 tons of ice blocks per day, after 1970 the trend of demand and ice block production 
continued to decline and only produced about 25 tons per day (PT. Alwi Assegaf, 2019). In 2012 the company established a drinking water production business "BIHAR" which processed river water into ready-to-drink water.

As a family company, the management of the company and its employees are clearly controlled by the family or those who have the family relationships. Duh (2015) states that employees employed by the family certainly cause problems because those who come from the family usually have low performance since they rely on emotional relationships, while employees who are not from the family will get a large workload and find it difficult to have a career because of the family company management pattern. In addition, family companies have limited networks, lack of cooperation and collaboration. Close relationships and good communication between future generations of family companies are a succession that leads to company performance (Ghee \& Halim, 2015). For this reason, family enterprises that generally come from the families need to avoid conflicts between roles where there are general demands on time spent with the tension created by disruptive work to carry out family-related responsibilities. This situation certainly has an impact on employee motivation.

According to Hasibuan (2017), work motivation greatly affects job satisfaction because it is associated with attitudes and situations where a positive attitude towards work situations can increase work motivation and vice versa negative attitudes towards work situations reduce performance. The work situation in question includes, among other things, work relations, work facilities, work climate, leadership policies, work leadership patterns and working conditions. Sutrisno (2016) argues that there are two motivations, namely intrinsic motivation and extrinsic motivation. The intrinsic motivation is the one coming from within employees who show strong behavior to develop themselves and achieve so that it contributes to the achievement of the company goals. While the extrinsic motivation is the motivation through suggestions or encouragement from outside individual employees such as organizational policies and workplace conditions. Therefore, both intrinsic and extrinsic motivations are actually a reflection of job satisfaction and employee performance achievement.

Job satisfaction is a combination of expectations and feelings of employees about their work. Satisfaction is achieved if what employees expect from their work can be fulfilled. Job satisfaction is also an expression of being happy or unhappy with the work environment, mental attitudes and an assessment of performance achievement (Siagian, 2014). Regarding the achievement of performance to reach the company goals, employee performance increases if it is based on the motivation and job satisfaction. Robbins (2016) states that job satisfaction is a behavior that arises from employees to contribute to the achievement of organizational goals accompanied by the fulfillment of employee desires such as salary, career, awards and so on. According to Mangkunegara (2016), employees showing their good work results constitute the results of the ability, expertise, and desires achieved being very directly related to how much motivation and employee satisfaction on achieving goals.

Based on the previously description, this study aimed to find out the effects of intrinsic motivation and extrinsic motivation on employee performance with job satisfaction as an intervening variable in PT. Alwi Assegaf Palembang. Quite interestingly, the testing of the variables examined in this study was those conducted in a family company closely related to motivation, job satisfaction and performance. In addition, the results of this study serve as recommendations for family companies in achieving their goals. 


\section{Literature Review}

\subsection{Performance}

Performance can be defined as the result of work achieved in accordance with the job description for a certain period (Veithzel, 2015). This shows that what has become the responsibility given to employees must be done according to the target. The achievement of job targets is an assessment of actual work performance and can become a comparison in assessing work performance among employees (Dessler, 2015).

Robbins (2016) defines performance as the operational effectiveness of an organization that shows success measured based on predetermined standards and criteria. The performance measurement indicators are as follows (Robbins, 2016):

1. Work quantity

The level at which the results of the activities carried out are close to perfect, in the sense of adjusting some ideal way of performing the activity or meeting the expected goals of an activity.

2. Quality of work

The amount produced in terms of the number of units, the number of activity cycles completed.

3. Punctuality

The level of an activity is completed at the desired initial time, viewed from the point of coordination with the output results and maximizes the time available for other activities.

4. Effectiveness

The level of use of human resources, the organization is maximized with the intention of increasing profits or reducing losses from each unit in the use of resources.

5. Independence

The degree to which an employee can perform his / her work function without asking for assistance from the supervisor or asking for the supervisor to interfere in order to avoid adverse results.

Mangkunegara (2016) states that the factors affecting performance are as follows:

a. Ability factor

Psychologically, the ability and reality ability (knowledge and skills) means that employees with an IQ above average (110-120) with adequate education for their positions and skilled in doing daily work will find it easier to achieve the expected performance. Therefore, employees need to be placed in jobs that match their expertise.

b. Motivational factor

Motivation is in the form of an employee's attitude in dealing with work situations. It is a condition that moves employees to achieve work goals.

Indicators of employee performance according to Mangkunegara (2016) are as follows:

1. Quality of Work

How well an employee does what is supposed to be done.

2. Work Quantity

How long an employee works in a day. This work quantity can be seen from the work speed of each employee.

3. Implementation of Duty

How far the employee is able to do his/her job accurately or without making any mistake.

4. Responsibility

Awareness of the obligation to do the work accurately or without making any mistake.

Wibowo (2016) states that performance is the result produced by certain jobs or activities at certain jobs for a certain period of time. The results of this work are the results of the abilities, 
expertise and desires achieved. For this reason, the best strategy for achieving organizational goals and improving performance is to motivate employees.

It can be concluded that employee performance is an assessment of work achievement towards job responsibilities whose measurements have interdependence so that it must be managed properly. By providing good motivation, the company's performance can be further improved.

\subsection{Motivation}

In general, work motivation is defined as an encouragement for someone to be able to do their work as expected. Luthans (2015) defines motivation as something that triggers a person to do something in which the motive is need, wish, desire or impulse. Meanwhile, Hasibuan (2017) puts forward an understanding that motivation is an individual's motivation to act in order to achieve goals or success. Individuals with a strong motivation will take a positive action to do something in achieving their goals, and conversely weak motivation will thwart the achievement of goals.

Maslow's theory of motivation states that in humans there are five levels of need (Robbins, 2016):

1. Physiological: includes hunger, thirst, shelter (clothing and housing) in accordance with the needs of these humans;

2. Security: includes security and protection from physical and emotional harm;

3. Social: affection that can be received well such as the relationship of friendship;

4. Appreciation: includes respect factors that are influenced internally such as self-esteem, achievement; and extrinsically influenced respect factors such as status, recognition from superiors and concern from someone; and

5. Self-actualization: encouragement that can shape an individual to become what $\mathrm{s} / \mathrm{he}$ can become; includes growth, reaching its potential, and self-introspection.

The Clayton Aldefer's theory known as Existence, Relatedness and Growth (ERG) Theory suggests that there are three main groups of needs, namely (Luthans, 2015):

1. Existence Needs: related to basic needs, including physiology, such as thirst and hunger.

2. The need for affiliation (Relatedness Needs): emphasizes the importance of relationships between individuals and other individuals. This need is also related to Maslow's Love Needs and Esteem Needs.

3. Growth Needs: the desire in a person to progress or to improve his/her personal abilities.

\subsubsection{Intrinsic Motivation}

According to Siagian (2014), intrinsic motivation arises from within individuals who have individual goals in obtaining job satisfaction and organizational goals in achieving their goals. The intrinsic motivation is closely related to job satisfaction. It is the willingness of individual employees regarding responsibility for completing their work (Wibowo, 2016).

Herzberg in Luthans (2015) defines intrinsic motivation as something that encourages someone to excel originates in that individual, which is better known as motivational factors with indicators as follows:

1. Achievement (success)

The success of an employee can be seen from the achievements s/he has achieved in order that an employee can succeed in carrying out his/her job, so the leader must study his/her subordinates and their work by providing opportunities for them so that the employees can try to achieve good results. When the employee has succeeded in doing his/her job, the leader must declare that success. 
2. Recognition

As a continuation of the successful implementation, the leaders must provide a statement of recognition of the employee's success which can be done in various ways such as giving a certificate of appreciation or cash.

3. Responsibility

Responsibility can be a motivating factor for subordinates if the leader avoids tight supervision, namely by allowing subordinates to work alone as long as the job allows and applies the principle of participation. The principle of participation applied by the leaders makes subordinates fully plan and carry out their own work.

\subsubsection{Extrinsic Motivation}

Siagian (2014) argues that extrinsic motivation is the motivation for work from outside the worker as an individual who requires him to carry out work with the fulfillment of work infrastructure, wages, benefits or work safety. Extrinsic motivation according to Luthans (2015) is motivation that comes from outside the individual that helps determine a person's behavior in a person's life, which was put forward by Herzberg known as the theory of hygiene factors, consisting of:

1. Compensation

Managers have the obligation to assess whether positions under their supervision receive rewards in the form of compensation, cash or others according to the work they do. Leaders must try to find out how the positions in the office are classified and what elements determine that classification.

2. Employment relationship

Healthy, friendly and appropriate relationships must exist among co-workers, superiors and subordinates.

3. Working conditions

Each manager can play a role in various matters so that the situation of each of his/her subordinates becomes more appropriate. For example, a special room for the unit, lighting, furniture, air temperature and other physical conditions. According to Hezberg, if good environmental conditions could be created, high achievement could be created, high achievement could be generated through concentration on ego needs and higher selfrealization.

It can be concluded that employee motivation, both intrinsic motivation and extrinsic motivation, is clearly needed to achieve company goals. Having the motivation, employees work with satisfaction because what they need as a result of the work they do is fulfilled.

\subsection{Job Satisfaction}

Jobs that provide job satisfaction for the workers are the jobs that are fun to do. Conversely, work that is not fun to do is an indicator of a sense of dissatisfaction at work. Job satisfaction encourages employees to be more enthusiastic at work and show a high contribution to work (Sedarmayanti, 2015). Companies must be aware of the will of the individuals and align their behavior with the needs, priorities and goals of the organization in acting for the needs of the organization (Veitzhal, 2015).

Greenbberg (2015) views job satisfaction from how far the work is done and completed, supervision as evidence of supervisors' attention to paying attention to employees, conducive conditions for fellow employees, promotion and provision of rewards according to work results. The problem of job dissatisfaction can be seen from absenteeism and late arrival at work, disharmony among employees or neglecting other employees and displaying bad behavior at work. 
Indicators for measuring job satisfaction according to Greenbberg (2015):

1. Satisfaction with Salary

Salary is the one that a person gets compared to the efforts that have been made, and the amount of salary received is the same as the those received by other people in the same position.

2. Satisfaction with the work itself

The extent to which the work is able to arouse a sense of pleasure and provide opportunities to learn to take responsibility for a particular task and to challenge an interesting job.

3. Satisfaction with the Promotion

Refers to the extent to which the company provides opportunities for advancement to each of its employees, providing the opportunity to be among different levels of the organization. The desire for promotion includes a desire for a higher income, social status, psychological growth and a desire for a sense of justice.

4. Satisfaction with Attitude of Supervisor / Supervision

The extent of attention to technical assistance and encouragement shown by superiors to subordinates. Superiors who have good personal relationships with subordinates and are able to understand the interests of their subordinates, and their participation in decision making have a positive impact on employee satisfaction.

5. Satisfaction with Co-workers

The degree to which co-workers are technically smart and socially supportive. For most employees, work is one way to meet social interaction needs. Therefore, fun co-workers can increase job satisfaction.

\subsection{Relationship Between Variables}

Intrinsic motivation and extrinsic motivation have a very important role for employees in obtaining job satisfaction and job achievement (Siagiaan, 2014). The following are several conducted studies related to the influence of intrinsic motivation and extrinsic motivation on job satisfaction or performance as follows:

1. Widyaputra and Dewi (2018) studied at PT. Bussan Auto Finance showed that a significant effect of intrinsic motivation on job satisfaction and employee performance.

2. Sulistyowati et al (2017) in they research found that extrinsic motivation significantly effect on job satisfaction of employees of Apotik Buchori.

3. Mantauv (2014) studied that the job satisfaction was an intervening variable of the influence of work motivation on employee performance at the Disaster Management Agency showing that there was a significant effect of intrinsic motivation and extrinsic motivation on job satisfaction and employee performance.

4. Putra (2013) in his research found that intrinsic motivation and extrinsic motivation had a significant effect on job satisfaction of employees of the human resources department of PT. Semen Gresik.

5. Muslih (2012), with the title of analysis of the influence of motivation on job satisfaction and employee performance at PT Sang Hyang Seri (Persero) Regional III Malang, showed that intrinsic and extrinsic motivation had a significant effect on employee performance.

6. The study conducted by Sipayung (2017) showed that there was a significant influence of intrinsic motivation and extrinsic motivation on national leadership on work productivity at the Office of Living Environment of Batam City.

7. Iriani (2010) conducting a study on the effect of intrinsic motivation, extrinsic motivation and work discipline on employee performance at the Office of Education of Sambas District concluded that the intrinsic motivation, extrinsic motivation and work discipline significantly influenced the employee performance.

8. Putro (2010) studied at PDAM Surabaya City showing that there was a significant effect of job satisfaction on employee performance. 
Based on the theory put forward by the experts and studies having been conducted by several researchers, this study proposed hypotheses as follows:

H1: Intrinsic motivation affects significantly positive on job satisfaction.

$\mathrm{H} 2$ : Extrinsic motivation affects significantly positive on job satisfaction.

$\mathrm{H} 3$ : Intrinsic motivation affects significantly positive on employee performance.

H4: Extrinsic motivation affects significantly positive on employee performance.

H5: Job satisfaction affects significantly positive on employee performance

The conceptual model in this study is as follows:

Figure 1. Research Framework

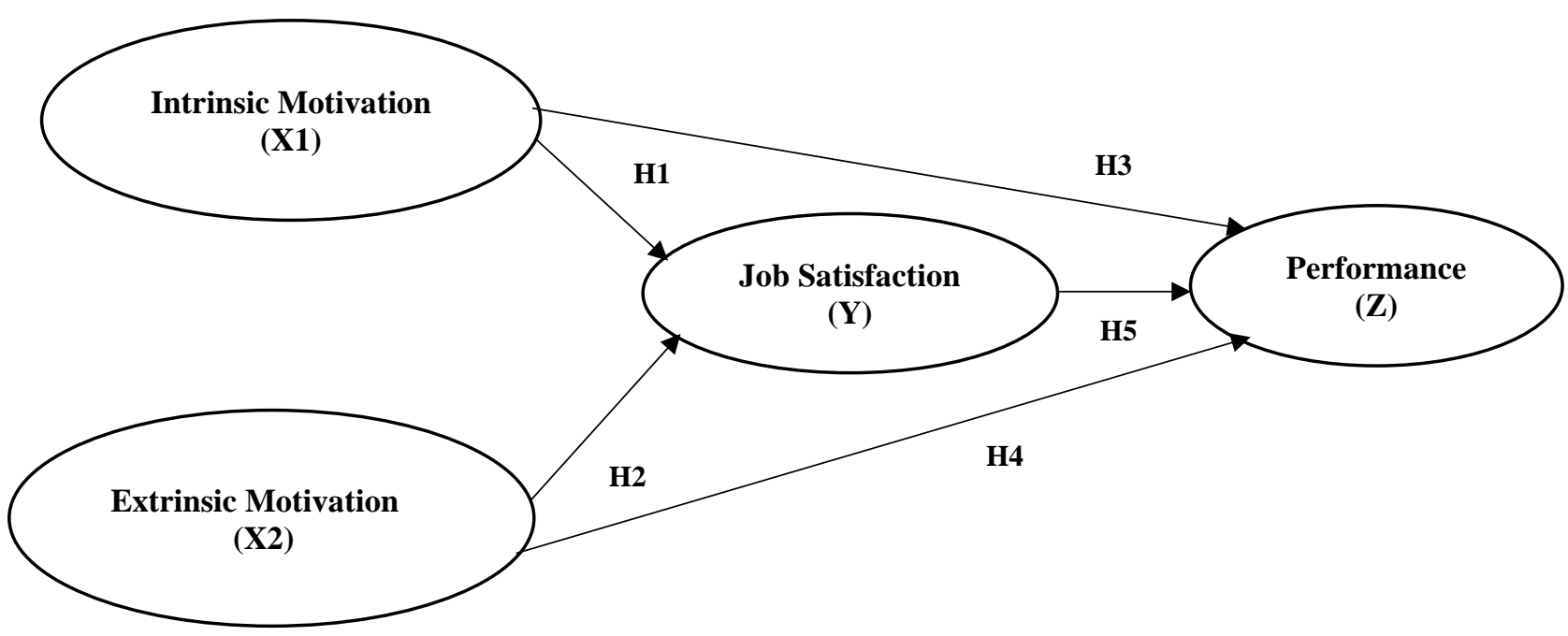

Source: Author, 2021

\section{Research Method}

This study was conducted at PT. Alwi Assegaf located at Jalan. DI. Panjaitan No.3, Bagus Kuning, Plaju Subdistrict, Palembang City, South Sumatra. The data used in this study were primary data, namely the data obtained directly from the respondents. The data were in the form of answers to research questions. The data were collected using a questionnaire list of statements (questionnaire) to employees. The respondents in this study were all employees of PT. Alwi Assegaf, amounting to 51 people. For analysis purposes, the questionnaire was divided into two parts, namely: (1) respondent description, containing respondent data: gender, age, education and years of service, (2) questions related to research variables: employee performance, intrinsic motivation, extrinsic motivation, and job satisfaction. According to Sugiyono (2017), each questionnaire item is weighted using a five-point Likert scale from the lowest score of 1 to the highest score of 5 with the categories of strongly disagree, disagree, rather disagree, agree, and strongly agree respectively.

Furthermore, the data were analyzed using variance-based Structural Equation Modeling (SEM), namely the Partial Least Square (PLS) method. The analysis stage was measuring the model (measurement model) with validity and reliability testing, then looking at the relationships among the variables (structural model) by looking at the R-Square value of the research model which was a test of goodness-fit mode, full structural model, and conducting hypothesis testing (Ghozali, 2014).

The operational definition of the research variables is as follows: 
Tabel1. Operational Definition of the Research Variables

\begin{tabular}{|c|c|c|}
\hline Variable & Definition & Dimensions \\
\hline Employee Performance $(\mathrm{Z})$ & $\begin{array}{l}\text { Performance is the work achieved by } \\
\text { employees in carrying out their duties } \\
\text { according to predetermined time and size } \\
\text { (Robbins, 2015) }\end{array}$ & $\begin{array}{l}\text { - Z1 Quantity } \\
\text { - Z2 Quality } \\
\text { - Z3 Punctuality } \\
\text { - Z4 Effectivity }\end{array}$ \\
\hline Intrinsic Motivation (X1) & $\begin{array}{l}\text { According to Herzberg, intrinsic motivation } \\
\text { can be interpreted as a driving force that } \\
\text { arises from within the individual (Luthans, } \\
\text { 2015) }\end{array}$ & $\begin{array}{l}\text { - X1.1 Success } \\
\text { - X1.2 Recognition } \\
\text { - X1.3 Responsibility }\end{array}$ \\
\hline Extrinsic Motivation (X2) & $\begin{array}{l}\text { According to Herzberg, extrinsic motivation } \\
\text { is an encouragement from outside of the } \\
\text { individual (Luthans, 2015) }\end{array}$ & $\begin{array}{l}\text { - X2.1 Kompensasi } \\
\text { - X2.2 Status pekerjaan } \\
\text { - X2.3 Kondisi Tempat Kerja }\end{array}$ \\
\hline Job Satisfaction (Y) & $\begin{array}{l}\text { Job satisfaction is an attitude that describes } \\
\text { the feelings of the individual towards his/her } \\
\text { job (Greenbberg, 2015) }\end{array}$ & $\begin{array}{l}\text { - Y1 Salary } \\
\text { - Y2 Job } \\
\text { - Y3 Promotion } \\
\text { - Y4 Supervision } \\
\text { - Y5 Co-worker }\end{array}$ \\
\hline
\end{tabular}

Source: Author, 2020

\section{Results and Discussion}

\subsection{Research Results}

\subsubsection{Descriptive Analysis of the Research Variables}

The subjects of this study were all employees of PT. Alwi Assegaf as many as 51 respondents. All employees are male with an age distribution of 25-60 years with the most dominant age group at the age of $35-50$ years as many as 37 people $(72.5 \%)$, while the smallest age group is $25-34$ as many as 10 people (19.5\%), and the rest over 50 years of age as many as 4 people $(7.8 \%)$. The employee education started from the junior high school level, the senior high school/STM and equivalent, and undergraduate level as many as 15, 30, 6 people respectively. The working period of the respondents ranged from 5 years to 20 years, dominated by those whose work period was 20 years as many as 33 people $(64.7 \%)$.

The respondents' answers to the question/statement items based on the variable indicators of this study showed an average value above 4.00 , meaning that all the research variables were in the high interpretation category (the lowest score started from 1 and the highest 5 based on the fivepoint Likert scale).

\subsubsection{Data Analysis Using the Smart-PLS \\ 4.1.2.1 Measurement Model}

The measurement model in this study was carried out by testing the validity and reliability. The convergent validity measures the magnitude of the correlation between the construct and the latent variable seen from the standardized loading factor. The standardized loading factor describes the magnitude of the correlation between each measurement item (indicator) and its construct. Ghozali (2014) suggests that a model is said to be valid if it has a loading value above 0.5 by comparing the Square root of average variance extracted (AVE) value of each construct with the correlation between constructs. If the square root value of AVE is higher than the correlation value between the extracts, then the good discriminant validity is achieved. The validity of each 
construct was tested by Average Variance Extracted (AVE). Testing the validity used the loading factor obtained by all items of questions that met the recommended values so that the indicators used to measure the variables in this study were valid.

The reliability test in this study was conducted by looking at the composite reliability value of the indicator block measuring the construct. According to Sugiyono (2017), if the value of composite reliability $\rho c>0.8$, the construct has high or reliable reliability and $\rho c>0.6$ is said to be quite reliable. In the analysis using PLS, the reliability test can also be strengthened by Cronbach's Alpha which is said to be good if $\alpha \geq 0.5$ and said to be sufficient if $\alpha \geq 0.3$ (Ghozali, 2014). The results of the reliability test in this study are presented in table 2 .

Table 2. Results of Reliability Test

\begin{tabular}{|l|c|c|c|}
\hline \multicolumn{1}{|c|}{ Variables } & $\begin{array}{c}\text { Composite } \\
\text { Reliability }\end{array}$ & $\begin{array}{c}\text { Cronbach } \\
\text { Alpha }\end{array}$ & Remarks \\
\hline Intrinsic Motivation & 0.851 & 0.807 & Reliable \\
\hline Extrinsic Motivation & 0.853 & 0.807 & Reliable \\
\hline Job Satisfaction & 0.918 & 0.894 & Reliable \\
\hline Employee Performance & 0.873 & 0.845 & Reliable \\
\hline
\end{tabular}

Source: Processed Primary Data Primer, 2020

\subsubsection{Structural Model}

The structural model of this study was conducted through bootstrapping to see the relationship among the variables by looking at the R-Square value of the research model which was a goodness-fit model test.

Table 3. Value of $R$-Square Adjusted

\begin{tabular}{|l|c|}
\hline \multicolumn{1}{|c|}{ Variable } & R-Square Adjusted \\
\hline Job Satisfaction & 0,369 \\
\hline Employee Performance & 0,404 \\
\hline
\end{tabular}

Source: Processed Primary Data, 2020

Table 3 shows the R-square value of the job satisfaction variable of 0.369 , meaning that the job satisfaction variable can be explained by the construct of intrinsic motivation and the construct of extrinsic motivation by 36.9 percent. For the employee performance variable, the R-Square value is 0.404 , meaning that the employee performance variable can be explained by the construct of intrinsic motivation, the construct of extrinsic motivation and the construct of job satisfaction by 40.4 percent.

\subsubsection{Full Model Structural}

The relationship among the variables can be seen from the following figure of the full structural model. 
Figure 2. Full Model Structural

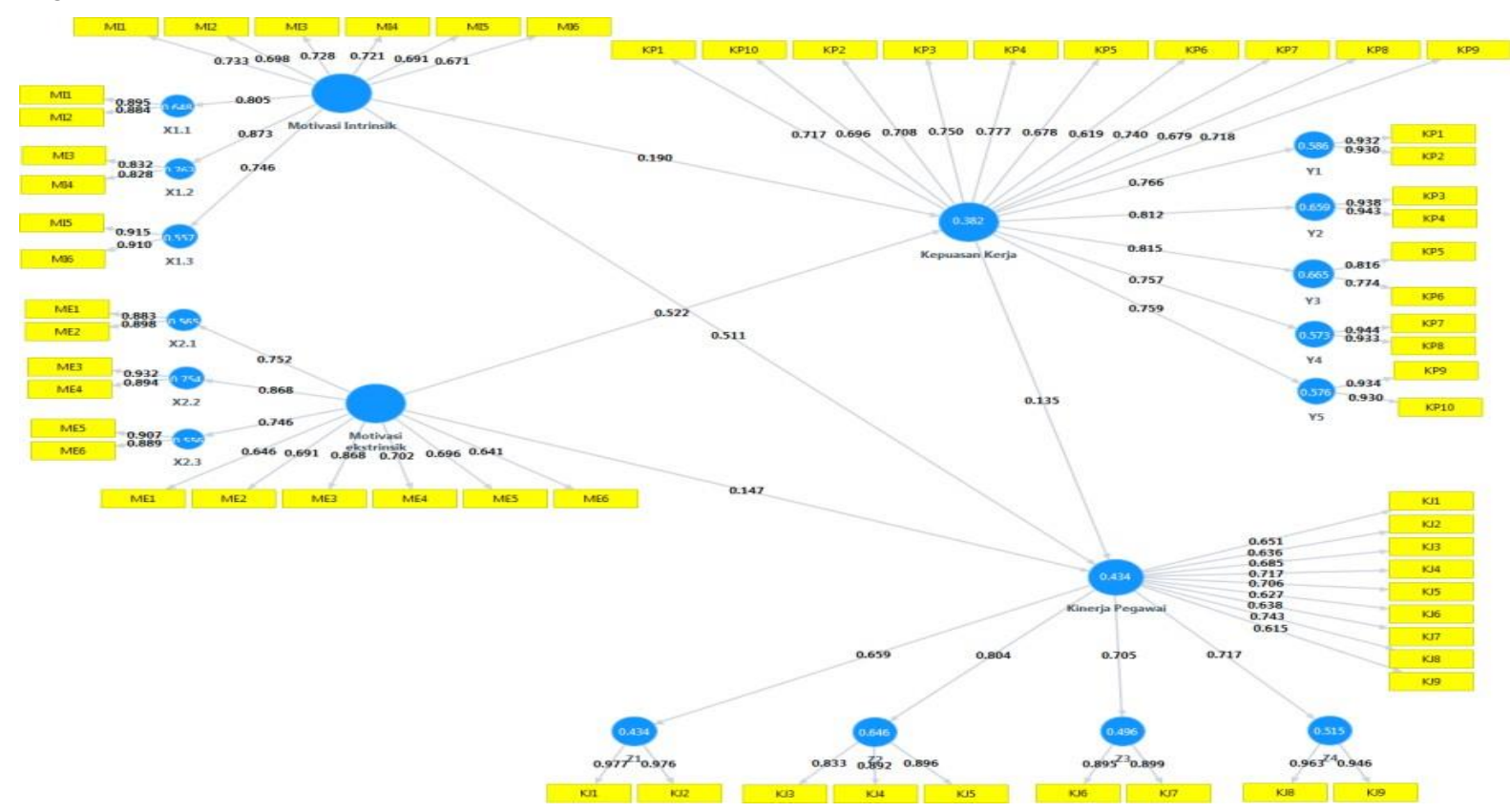

Source: Data Process, 2020

\subsubsection{Hypothesis Test}

This study proposed 5 hypotheses based on the values contained in the structural model analysis, looking at the significance of the influence of exogenous variables consisting of: Extrinsic Motivation (EM), Intrinsic Motivation (IM), and Job Satisfaction (JS) on endogenous variables Performance (Pf) by looking the significance of the path coefficient obtained from the $t$ statistic value and the standardized path coefficient value.

Table 4. Path Coefficient

\begin{tabular}{|l|c|c|l|l|}
\hline \multicolumn{1}{|c|}{$\begin{array}{c}\text { Path } \\
\text { Coffficient }\end{array}$} & $\begin{array}{c}\text { Original } \\
\text { Sample }\end{array}$ & $\begin{array}{c}\text { Sample } \\
\text { Mean }\end{array}$ & T-stat & $\boldsymbol{p}$-Values \\
\hline IM -> JS & 0,193 & 0,184 & 2,000 & 0,049 \\
\hline EM -> JS & 0,513 & 0,526 & 5,057 & 0,000 \\
\hline IM -> Pf & 0,513 & 0,532 & 5,257 & 0,000 \\
\hline EM -> Pf & 0,154 & 0,140 & 1,471 & 0,146 \\
\hline JS -> Pf & 0,123 & 0,131 & 1,332 & 0,187 \\
\hline
\end{tabular}

Source: Processed Primary Data, 2020

From the path in Table 4, the fourth and fifth hypotheses had a p-value greater than 0.05 , meaning that extrinsic motivation and job satisfaction did not have a significant effect on performance. 


\subsection{Research Result Discussion}

\subsubsection{Effects of Intrinsic Motivation on Employee Job Satisfaction}

Intrinsic motivation is a driving force that arises from within each person, so that it satisfies and encourages people to work well (Herzberg in Luthans, 2015). Meanwhile, the job satisfaction will show individual attitudes towards their work (Greenbberg, 2015). Therefore, the motivation both intrinsically and extrinsically affects the job satisfaction. The results of the studies conducted by Widyaputra and Dewi (2018), Putra (2013) and Muslih (2012) showed that there was a positive influence between intrinsic motivation and job satisfaction explaining that the intrinsic motivation had a significant effect on employee job satisfaction. The results of this study support the theory and research conducted previously where the results of this study indicate a significant effect of intrinsic motivation on employee job satisfaction ( $p$-value $0.049<0.05$ ). For this reason, the company, through its management, has to pay attention to and assess the performance or success of its employees fairly, recognize achievements and increase employee responsibility for their work by ignoring the status of a family company so that the company can achieve its goals.

\subsubsection{Effects of Extrinsic Motivation on Employee Job Satisfaction}

Extrinsic motivation comes from outside of the individual causing him/her to have intention to take an action. Herzberg argues that extrinsic motivation is a work driver that comes from outside the worker as an individual in the form of a condition that requires him to do the job optimally (Luthans, 2015). The results of studies conducted by Sulistyowati et al (2017), Mantauv (2013), Putra (2013) and Muslih (2012) showed that extrinsic motivation had a significant effect on employee satisfaction. The results of these studies provide a contribution which indicates a significant effect of extrinsic motivation on job satisfaction (p-value $0.000<0.05$ ). Through the provision of appropriate compensation, clear work status, conducive and comfortable workplace conditions, the company should focus on increasing employee contributions to the company.

\subsubsection{Effects of Intrinsic Motivation on Employee Performance}

Employee loyalty and commitment is needed by the company through encouragement that comes from individuals so that it spurs employees to be creative and innovate at work. A strong drive from within employees creates good performance in the hope that the organization pays attention to their needs. The study results by Sipayung (2017), Maulana (2015), Muslih (2012) and Iriani (2010) proved that intrinsic motivation has a positive effect on employee performance. In this study, the p-value was $0.000<0.05$, meaning that there was a significant positive effect between intrinsic motivation and employee performance. The higher the intrinsic motivation is, the higher the employee performance will be.

\subsubsection{Effects of Extrinsic Motivation on Employee Performance}

The study conducted by Sulistyowati et al (2017), Maulana (2015), Muslih (2012) and Iriani (2010) showed that there was a significant effect of extrinsic motivation on job satisfaction. However, the different results of the studies conducted by Murty (2012) using Partial Least Square showed that the extrinsic motivation did not have a significant effect on the performance of employees of Palangka Raya University. The results of this study showed that the extrinsic motivation had no significant effect on the employee performance ( $p$-value $0.146>0.05$ ). Consequently, it can be concluded that the extrinsic motivation whose indicators were compensation, job status and workplace conditions had no effect on the performance of employees of PT. Alwi Assegaf Palembang.

\subsubsection{Effects of Job Satisfaction on Employee Performance}

Employee job satisfaction is an employee's perspective, both positive and negative about their work. Employees who have high job satisfaction result in these employees becoming more loyal to the organization, motivated, feeling happy at work, and ultimately achieving company goals 
and vice versa. The results of this studied showed that job satisfaction whose indicators were compensation, job status and workplace conditions had no effect on the performance of employees (p-value $0.187>0.05$ ) of PT. Alwi Assegaf Palembang. The insignificant result of the effects of job satisfaction on the performance was shown in the study of Henis et al. (2016) on PDAM of Malang City.

\subsubsection{Effects of Intervening Variable}

The effects of intrinsic motivation on employee performance with job satisfaction as an intervening variable in this study showed that the job satisfaction did not have a significant effect on performance. In other words, the indirect effect of intrinsic motivation on performance through the job satisfaction was not significant, that is to say, the job satisfaction was not a variable that mediated the effect of intrinsic motivation on the performance.

The effect of extrinsic motivation on employee performance with job satisfaction as an intervening variable showed that the job satisfaction did not have a significant effect on the performance. In this way, the indirect effect of extrinsic motivation on the performance through job satisfaction was not significant, or in other words, the job satisfaction was not a variable that mediated the effect of extrinsic motivation on the performance.

\section{Conclusion}

1. Intrinsic motivation and extrinsic motivation have a significant positive effect on employee job satisfaction.

2. Intrinsic motivation has a significant positive effect on employee performance, while extrinsic motivation has no significant effect on employee performance.

3. Job satisfaction does not have a significant effect on employee performance, therefore the measurement of the mediating effect of job satisfaction variable on the influence of intrinsic motivation and extrinsic motivation on employee performance is declared null and void in this study.

4. Further research needs to explore other factors beyond intrinsic motivation, extrinsic motivation, and job satisfaction, for example, work discipline and leadership to improve performance of the employees of PT. Alwi Assegaf Palembang.

\section{Bibliography}

Dessler, G. (2015). Manajemen Sumber Daya Manusia. Salemba Empat. Jakarta.

Duh, M. (2015). Succession Process: A Chance for Rebirth or Failure of a Family Business. International Journal of Business and Management, 10 (3).

Ghee, W.Y., Ibrahim, M.D., \& Abdul-Halim, H. (2015). Family Business Succession Planning: Unleashing the Key Factors of Busi-ness Performance. Asian Academy of Man-agement Journal, 20(2), 103-126.

Ghozali. (2014). Structural Equation Modeling Metode Alternatif Dengan Partial Least Square (PLS). Edisi 4. Badan Penerbit Universitas Diponegoro. Semarang.

Greenbberg, Gardner, W. Jhon. (2015)On Leadership. The Free Press. ADivision of Mac Millan, Inc. New York.

Hasibuan, M. S. P. (2017). Manajemen Sumber Daya Manusia, Edisi Revisi. Bumi Aksara. Jakarta.

Henis Fiqih Amalini, Mochammad Al Musadieq, Tri Wulida Afrianty. (2016). Pengaruh Locus of Control Terhadap Kepuasan Kerja dan Kinerja (Studi Pada Karyawan PDAM Kota Malang). Jurnal Administrasi Bisnis (JAB), 35(1):68-77. 
Indrawati, Ayu Desi. (2013). Pengaruh Kepuasan Kerja terhadap Kinerja Karyawan dan Kepuasan Pelanggan pada Rumah Sakit Swasta Di Kota Denpasar. Jurnal Manajemen Strategi Bisnis, dan Kewirausahaan, 7(2):135-142.

Iriani, Ida, N. (2010). Pengaruh Motivasi Intrinsik, Motivasi Ekstrinsik dan Disiplin Kerja Terhadap Kinerja Pegawai pada Kantor Dinas Pendidikan Kabupaten Sambas. Jurnal Aplikasi Manajemen, Vol 8, No 2.

Luthans, Fred, Luthans, B. C., Luthans, K. W. (2015). Organizational Behavior: an evidencebased approach 13th ed. Information Age Publishing. North Carolina.

Mangkunegara, A. P. (2016). Manajemen Sumber Daya Manusia Perusahaan. Remaja Rosdakarya. Bandung.

Mantauv, C,S. (2014). Kepuasan Kerja merupakan variabel intervening Pengaruh antara Motivasi Kerja terhadap Kinerja Pegawai (Studi Empirik pada Badan Penanggulangan Bencana). Ejurnal aplikasi ekonomi vol 2 no 1 STIE Yappas

Maulana., Fakhrian Harza., Hamid, Djamhur., Mayoan, Yuniadi. (2015). Pengaruh Motivasi Intrinsik, Motivasi Ekstrinsik Dan Komitmen Organsasi terhadap Kinerja Karyawan Pada Bank Btn Kantor Cabang Malang. Jurnal Administrasi Bisnis (JAB), 22(1):1-8.

Murty Windy Aprilia., Hundiwinarsih Gunasti. 2012. Pengaruh Kompensasi, Motivasi dan Komitmen Organisasi Terhadap Kinerja Karyawan bagian Akutansi (studi kasus pada perusahaan manufaktur di Surabaya). Jurnal The Indonesian Accounting Review, 2(2):6470

Muslih, B. (2012). Analisis Pengaruh Motivasi Terhadap Kepuasan Kerja dan Kinerja Karyawan di PT Sang Hyang Seri (Persero) Regional III Malang. Jurnal Aplikasi Manajemen, 10(4).

Eko Purwanto Putro. (2010). Pengaruh Faktor- Faktor Kepuasan Kerja terhadap Kinerj Karyawan Pusat Pendidikan Komputer Akuntansi Imka Di Surakarta. Diakses: http://repository.unair.ac.id/2794/2/gdlhub-gdl-s1-2011-putroekopu-15370-38710pt\%20Fulltext.pdf

PT. Alwi Assegaf. (2019). Catatan Produksi Perusahaan. PT. Alawi Assegaf. Palembang

Putra A. K., Frianto, A. (2013). Pengaruh Motivasi Intrinsik dan Motivasi Ekstrinsik Terhadap Kepuasan Kerja. Jurnal Manajemen Universitas Surabaya.

Robbins, S. P., Coulter, M. (2016). Management. 13th Edition. Pearson Educaton. London.

Sedarmayanti. (2017). Perencanaan dan Pengembangan Sumber Daya Manusia. PT RefikaAditama. Bandung.

Siagian, P. Sondang. (2014). Manajemen Sumber Daya Manusia. Bumi Aksara. Jakarta.

Sipayung, L,M, Zamor, R. (2017). Pengaruh Motivasi Instrinsik, Motivasi Ekstrinsik dan Kepemimpinan Transformasional terhadap produktivitas kerja di Bidang Pengelolaan Persampahan pada Dinas Lingkungan Hidup Kota Batam. Jurnal Bening Prodi Manajemen Universitas Riau Kepulauan Batam.

Sugiyono. (2017). Metode Penelitian Kuantitatif, Kualitatif, dan R\&D. CV. Alfabeta. Bandung. Sulistyowati, Akhmadi and Lutfi. (2017). Pengaruh Motivasi Ekstrinsik Dan Lingkungan Kerja Fisik Terhadap Kinerja Karyawan Dengan Kepuasn Kerja Sebagai Variabel Intervening. Jurnal Riset Bisnis dan Manajemen Tirtayasa (JRBMT), Vol.1 (2): hh.137-148 (Nopember 2017) ISSN (Online) 2599-0837

Sutrisno, Edy. (2016). Manajemen Personalia Dan Manajemen Sumber Daya Manusia. Prenada Media Group. Jakarta

Veithzal Rivai Zainal, S. (2015). Manajemen Sumber Daya Manusia Untuk Perusahaan. Edisi ke7. PT RAJAGRAFINDO. Depok.

Wibowo. (2016). Management Kinerja. Rajawali Press. Jakarta

Widyaputra, Ketut Andika; Dewi, A.A Sagung Kartika. (2018). Pengaruh Motivasi Intrinsik Terhadap Kepuasan Kerja Dan Kinerja Karyawan Pada Pt Bussan Auto Finance. E-Jurnal Manajemen, [S.1.], v. 7, n. 1, p. 85 - 104, jan. 2018. ISSN 2302-8912 
Journal Management, Business, and Accounting p-ISSN 2086-5090, e-ISSN: 2655-8262

Vol. 20, No. 1, April 2021

\section{Copyright Disclaimer}

Copyright for this article is retained by the author(s), with first publication rights granted to the journal. 